\title{
Predictors of Severe and Permanent Disability in Children Evaluated in Health Boards: A Single-Center Study
}

\author{
Özürlü Sağlık Kurulunda Değerlendirilen Çocuklarda Ağır ve Sürekli Özürlülüğün Yordayıcıları: \\ Tek Merkezli Bir Çalışma
}

\author{
Gülen GÜLER AKSU ${ }^{1}$ \\ (i) 0000-0001-9555-3916 \\ Pelin DAĞ $\breve{2}^{2}$ \\ (D) 0000-0002-5051-3459 \\ Meryem Özlem KÜTÜK ${ }^{3}$ \\ (D) 0000-0002-2918-7871 \\ Ali Evren TUFAN ${ }^{4}$ \\ (1) 0000-0001-5207-6240 \\ Fevziye TOROS ${ }^{1}$ \\ (D) 0000-0001-5402-9157 \\ Didem DERICI I YILDIRIM ${ }^{5}$ \\ (D) 0000-0001-7709-6133 \\ Ali BİÇER ${ }^{6}$ \\ (D) 0000-0001-9783-0825
}

\begin{abstract}
${ }^{1}$ Mersin University Faculty of Medicine Department of Child and Adolescent Psychiatry, Mersin, Turkey ${ }^{2}$ Mersin City Training and Research Hospital Department of Child and Adolescent Psychiatry, Mersin, Turkey

${ }^{3}$ Başkent University Faculty of Medicine Department of Child and Adolescent Psychiatry, Adana, Turkey

${ }^{4}$ Acıbadem University Faculty of Medicine Department of Child and Adolescent Psychiatry, İstanbul, Turkey

${ }^{5}$ Mersin University Faculty of Medicine Department of Biostatistics, Mersin, Turkey

${ }^{6}$ Mersin University Faculty of Medicine Department of Physical Therapy and Rehabilitation, Mersin, Turkey
\end{abstract}

\section{Corresponding Author Sorumlu Yazar \\ Gülen GÜLER AKSU}

dr.gulen@hotmail.com

Received / Geliş Tarihi : 27.11.2019 Accepted / Kabul Tarihi : 31.03.2020 Available Online /

Çevrimiçi Yayın Tarihi : 25.04.2020

\begin{abstract}
Aim: The aim of this study is to determine the severe and permanent disability of the children evaluated in the disabled health boards and to evaluate the predictors of severe and permanent disability.

Material and Methods: Records of 1482 children who were referred to a university hospital health board for disability between the years 2013-2018 were screened retrospectively.

Results: More than half (52.2\%) of the children had a single psychopathology. $83.5 \%$ of the cases were severely disabled and $66.5 \%$ were permanently disabled. Severely disabled children were significantly more likely to have psychiatric, pediatric, neurological, orthopedic and otorhinolaringologic disorders. Permanent disability was significantly more frequent among patients with pediatric, ophthalmologic and cardiac disorders while children with psychopathologies were significantly less likely to have permanent disability. Mental retardation/intellectual developmental disorder levels differed in rates of permanent disability with pair-wise comparisons revealing that severe mental retardation/intellectual developmental disorder was the main factor. Severe disability was significantly more common among children younger than 8 years while permanent disability was more common among children $>3$ years. Children with psychopathology were 4.1 times more likely to have severe disability and this further increased to 15.3 for those with mental retardation/intellectual developmental disorder.

Conclusion: This is the first study to evaluate the factors that affecting the decisions of permanent and severe disabilities in disability health boards. Comprehensive results have been achieved despite low generalizability. To provide consistent reports, further and multicenter studies on factors associated with severe and permanent disabilities in children are needed. Keywords: Disability; disabled children; intellectual disability; disability evaluation.
\end{abstract}

ÖZ

Amaç: Bu çalışmanın amacı özürlü sağlık kurullarında değerlendirilen çocuklarda ağır ve sürekli özürlüğü belirlemek ve ağır ve sürekli özürlülüğün yordayıcılarını değerlendirmektir.

Gereç ve Yöntemler: Bir üniversite hastanesinin özürlü sağlık kuruluna 2013-2018 yılları arasında başvuran 1482 çocuğa ait kayıt geriye dönük olarak değerlendirildi.

Bulgular: Çocukların yarısından fazlasında $(\% 52,2)$ bir psikopatoloji saptandı. Olguların $\% 83,5$ 'i ağır özürlü ve \%66,5'i ise sürekli özürlüydü. Ağır özürlü olan çocuklarda psikiyatrik, pediatrik, nörolojik, ortopedik bozukluklar ve kulak burun boğaz ile ilișkili bozukluklar görülme olasılığı anlamlı şekilde daha fazlaydı. Pediatrik, oftalmolojik ve kardiyak bozuklukları olan çocuklar arasında sürekli özürlülük anlamlı şekilde daha fazla iken, psikopatolojisi olan çocuklarda sürekli özürlülük görülme olasılığı anlamlı olarak daha düşüktü. Mental retardasyon/entelektüel gelişimsel bozukluk düzeylerinin sürekli özürlülük oranları açısından çift yönlü karşılaştırmalar ile farklılaşması ağır mental retardasyon/entelektüel gelişimsel bozukluğun ana faktör olduğunu ortaya koymuştur. Ağır özürlülük 8 yaşından küçük çocuklar arasında anlamlı şekilde daha yaygın iken sürekli özürlülük ise 3 yaşından büyük çocuklar arasında daha yaygındı. Psikopatolojisi olan çocuklarda ağır özürlülük görülme olasılığı 4,1 kat daha fazlaydı ve bu durum mental retardasyon/entelektüel gelişimsel bozukluğu olanlar için 15,3'e kadar yükselmiştir.

Sonuç: Bu çalışma özürlü sağlık kurullarında sürekli ve ağır özürlülük kararlarını etkileyen faktörleri değerlendiren ilk çalışmadır. Genellenebilirliği düşük olmasına rağmen kapsamlı sonuçlar elde edilmiştir. Çocuklarda sürekli ve ağır özürlülükle ilişkili faktörlerle ilgili tutarlı raporların verilebilmesi adına daha fazla ve çok merkezli çalışmalara ihtiyaç vardır.

Anahtar kelimeler: Engellilik; engelli çocuklar; entellektüel engellilik; engellilik değerlendirmesi. 


\section{INTRODUCTION}

Disability is defined as any impairment, activity limitations, or participation restrictions that result from the health condition or from personal, societal, or environmental factors in typical daily activities and interactions in the individual's life (1).

The Global Burden of Disease study estimates that the number of persons with disabilities over the age of 15 is approximately 975 million (19.2\%) through the world, while the World Health Survey reports this number as 785 million (15.6\%) (2). According to a nation-wide disability survey conducted in 2002 in Turkey, while the people with disabilities constitute $12.3 \%$ of the total population, the disabled population aged between 0 and 19 is about $8.8 \%$ of the total population (3).

In Turkey, disabled children and adolescents are brought by their parents to the health boards for certification and classification of their impairment. This certification is required in order for them and their families to benefit from the rights of the disabled. Health boards are responsible for providing medical reports on health status, disability rates, educational and social rights and employability of persons (for those $>18$ years old). The legal basis of these reports is the "Regulation on the Disability Measure, Classification and Health Board Reports for Disabled", which was updated in 2013 and was put into force in 2016 (4). The rate of disability is determined by the percentage $(\%)$ corresponding to the rates of disability in this regulation. The ratings are similar to baremas used in various countries and multiple impairments are combined with the Balthazard Formula (5). According to this regulation, persons with a disability rate of $50 \%$ or more and who cannot fulfill their daily living activities without the help of others are considered "severely handicapped". The duration of the report is also determined by whether the person's disability is continuous or not (6). However, no clear statements in the regulation exits as to which diseases and under which circumstances will the child be categorized as severely and/or permanently disabled. Discretion on the disabilities remains delegated to the physicians in the health boards for disabled, and it is well known in the clinical practice that there might be differences of opinion and a lack of uniformity exist across the different health boards. This ambiguity leads to discrepancy between reports, the inability of patients to benefit from social and educational rights at the same time, and the increase in objections to reports. Given these reasons, in this study, we aimed to evaluate the sociodemographic and clinical characteristics of children and adolescents who applied to the health board of a tertiary treatment center, and factors affecting severe and persistent disability decisions.

\section{MATERIAL AND METHODS}

Records of children aged 18 and younger who were referred to Health Board for Disability of Mersin University Medical Faculty between the years 2013-2018 were screened retrospectively. Age, gender, disability rates, disability-causing illnesses, disabling psychiatric disorders, severe and/or persistent disability, and reporting purposes were examined. Clinical factors and diseases that require decisions of severe and/or persistent disability were assessed. Ethical approval was obtained for this study and that participation involved informed consent (Mersin University Clinical Researches Ethic Committee, approval date 22/02/2018, number 2018/84).

\section{Statistical Analysis}

Statistical analyses were conducted with Statistica 13.3.1 software (TIBCO Software Inc., Palo Alto, CA, USA). Quantitative data are summarized in means and standard deviations while categorical data are summarized as counts and frequencies. Chi-square test was used to evaluate bivariate associations between categorical variables. Multiple logistic regression analyses were used to evaluate variables displaying significant associations. For quantitative variables, Receiver Operating Characteristic (ROC) analysis was used to determine appropriate threshold. Two-tailed p value was set at 0.05 .

\section{RESULTS}

Within the specified time frame 1482 children $(63.1 \%$ male, $n=935$ ) were evaluated by the Health Board for Disability of Mersin University Medical Faculty. Mean age was $6.6 \pm 5.0$ (range, 0-18) years. There were 172 missing values and all percentages were calculated from 1310 sample size. More than half of the children had a single psychopathology $(52.2 \%, \mathrm{n}=684)$ while $14.8 \%$ $(n=194)$ of the children were diagnosed with two or more psychopathologies. Most frequent diagnoses were mental retardation/intellectual developmental disorder (MR/IDD, $52.9 \%$ ), autism spectrum disorders (ASD, 14.0\%) and attention deficit/hyperactivity disorder (ADHD, 4.2\%). Although the Turkish regulation suggests using Developmental Delay for children $<6$ years old rather than $\mathrm{MR} / \mathrm{IDD}$, those groups were conflated for this analysis. Grades of MR/IDD in order of frequency were mild $(n=422,32.2 \%)$, moderate $(n=294,22.4 \%)$ and severe $(\mathrm{n}=141,10.8 \%)$. Additionally Borderline Intellectual Functioning was observed in 37 (2.8\%) of the patients.

Among the whole sample severe disability was found in $83.5 \%(n=1238)$ and permanent disability was found in $66.5 \%(n=986)$. Severely handicapped children were significantly more likely to have psychiatric $(\mathrm{p}<0.001)$, otorhinolaringologic $(p<0.001)$, pediatric $\quad(p<0.001)$, neurological $(p<0.001)$ and orthopedic $(p=0.007)$ disorders. Among psychopatologies; severe disability was significantly more common among those with MR/IDD $(\mathrm{p}<0.001)$ and those with mild/moderate and severe MR/IDD ( $p<0.001)$. Children with severe disability were significantly younger than those without $(\mathrm{p}<0.001)$. Area Under Curve (AUC) was significant and 8 years emerged as a significant but weak cut-off to distinguish severe disability (AUC=0.670, p<0.001, Figure 1).

Permanent disability was significantly more frequent among patients with pediatric, ophthalmologic and cardiac disorders $(\mathrm{p}<0.001)$ while children with psychopatologies were significantly less likely to have permanent disability $(\mathrm{p}<0.001) . \mathrm{MR} / \mathrm{IDD}$ levels differed in rates of permanent disability $(\mathrm{p}<0.001)$ with pair-wise comparisons revealing that severe MR/IDD was the main factor $(p<0.001)$. Children classified as permanently disabled were significantly older $(\mathrm{p}<0.001)$. ROC analysis revealed that children $<3$ years old were provided with temporary reports while those $>3$ years were more likely to be diagnosed with permanent disability (AUC $=0.700, \mathrm{p}<0.001$, Figure 2 ). 
Logistic regression analysis revealed that for this sample (Hosmer-Lemeshow test was used for model evaluation and model fits was good, $\mathrm{HW}=12.899, \mathrm{p}=0.075$ ), children with psychopathology were 4.060 times more likely to have severe disability $(95 \% \mathrm{CI}=1.558-10.580, \mathrm{p}=0.004)$ and this further increased to 15.305 for those with MR/IDD (95\% CI=7.112-32.937, $\mathrm{p}<0.001$, Table 1).

The probability of receiving permanent report rises by 4.324 times as the age increases $(95 \% \mathrm{CI}=3.282-5.698$, $\mathrm{p}<0.001)$. The probability of having a psychiatric condition is 0.535 times lower than for those who are not on a permanent report $(95 \% \mathrm{CI}=0.360-0.796, \mathrm{p}=0.002$, Table 2$)$.

\section{DISCUSSION}

This retrospective chart-review study aimed to evaluate socio-demographic and clinical features of patients applying to the health board of a university hospital and to determine predictors of severe and permanent disabilities. As a result, we found that more than half of the sample had psychopathologies while severe and permanent disabilities were common. Severe disability was significantly more common among children younger than 8 years while permanent disability was common among children $>3$ years. In the Turkish literature, studies related to health board reports for disabled (HBRD) examined the sociodemographic characteristics and frequency of disability of the patients in general, but no study was

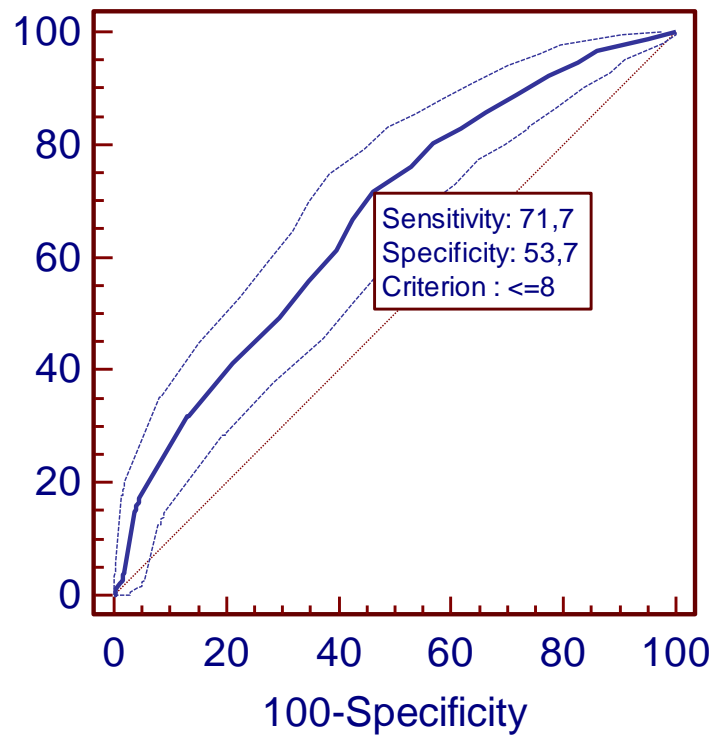

Figure 1. Receiver operating characteristics curve to determine age for severe disability

Table 1. Factors affecting odds of severe disability

\begin{tabular}{lccc}
\hline & OR & $\mathbf{9 5 \%}$ CI & p \\
\hline Age & 1.590 & $1.027-2.456$ & $\mathbf{0 . 0 3 7}$ \\
Otorhinolaringologic & 2.692 & $1.150-6.302$ & $\mathbf{0 . 0 2 2}$ \\
Psychopathology & 4.060 & $1.558-10.580$ & $\mathbf{0 . 0 0 4}$ \\
MR/IDD & 15.305 & $7.112-32.937$ & $<\mathbf{0 . 0 0 1}$ \\
Pediatric & 7.734 & $4.485-13.337$ & $<\mathbf{0 . 0 0 1}$ \\
Neurologic & 2.021 & $1.070-3.818$ & $\mathbf{0 . 0 3 0}$ \\
Orthopedical & 1.261 & $0.715-2.222$ & 0.423 \\
\hline OR· Odds Ratio, CI: Confidence Interval & &
\end{tabular}

OR: Odds Ratio, CI: Confidence Interval conducted to evaluate the factors affecting severe and permanent disability decisions in HBRD.

Previous studies from Turkey reported that male children and those with psychopathologies were significantly more frequent among HBRD applications (7-9). Another study involving 1112 children reported that most common diagnoses were global developmental delay (61.1\%) and ASDs $(15.0 \%)$ for the <6 years, while most common diagnoses were MR/IDD (61.9\%) and learning disorders (2.8\%) for $>6$ years (8). Another study found that most frequent diagnoses were MR/IDD (36.1\%), learning disorders $(20.2 \%)$ and ASDs $(11.1 \%)$ among its sample of HBRD applications (10). Similar to those reports, we also found a preponderance of males and those with psychopathologies among our sample. Also, similarly most common diagnoses in our sample were MR/IDD, ASDs and ADHD.

Previous studies from Turkey reported that most frequent reason of application to HBRD was to receive a special education report for Individual Education Plans (IEPs) (8,10-13). However, the most common reason of application in our study was procuring financial aids (i.e. $75.0 \%$ ) while special education reports for IEPs formed only $23.4 \%$ of the reasons. This difference may be due to the facts that previous studies focused on children with mental disorders only (11-14), and that the high rates of severe disability in our study (i.e. 83.5\%). The parents in

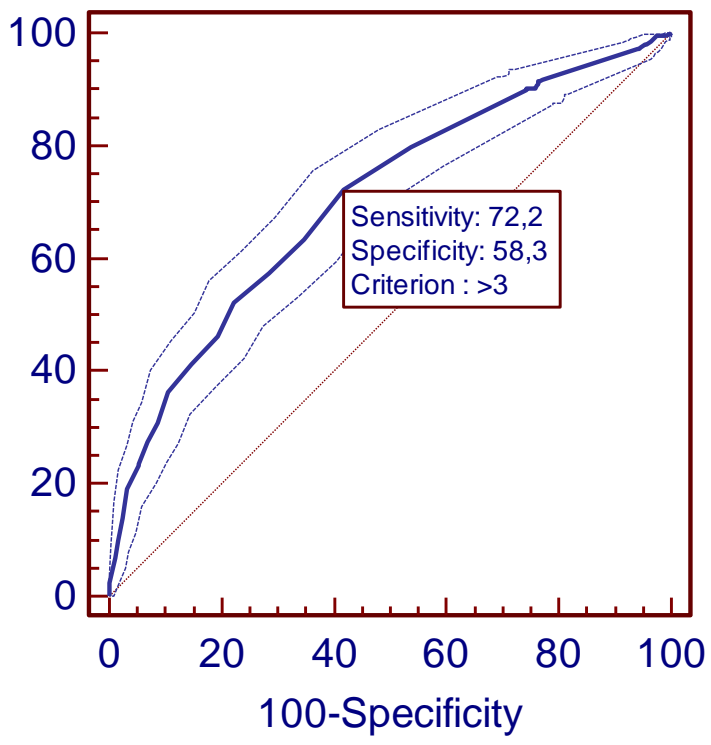

Figure 2. Receiver operating characteristics curve to determine age for permanent disability

Table 2. Factors affecting odds of permanent disability

\begin{tabular}{lccc}
\hline & OR & $\mathbf{9 5 \%} \mathbf{C I}$ & $\mathbf{p}$ \\
\hline Age & 4.324 & $3.282-5.698$ & $<\mathbf{0 . 0 0 1}$ \\
Psychiatric condition & 0.535 & $0.360-0.796$ & $\mathbf{0 . 0 0 2}$ \\
MR & 0.722 & $0.490-6.514$ & 0.100 \\
Cardiac & 2.841 & $1.942-4.156$ & $<\mathbf{0 . 0 0 1}$ \\
Pediatric & 4.452 & $3.043-6.514$ & $<\mathbf{0 . 0 0 1}$ \\
Ophthalmologic & 2.735 & $1.736-6.514$ & $<\mathbf{0 . 0 0 1}$ \\
\hline
\end{tabular}


our sample may have focused on financial aids for their children's disability and neglected the rehabilitation process. This hypothesis should be evaluated with further studies using interviews with parents for aims of their applications.

Rates of severe and permanent disability in previous studies vary according to sampling sources $(9,13,15,16)$. According to Global Burden of Disease, the rate of severe disability in children aged between 0 and 14 was $0.7 \%$ and the rate of moderate to severe disability was $5.1 \%$ (15). In another study from Turkey, which conducted a chart review of children's HBRDs rates of severe and permanent disability were $45.9 \%$ and $17.6 \%$, respectively (13). The authors interpreted those results as reflecting the relative rarity of chronic disorders in childhood as well as the unwillingness of clinicians to ascribe "permanence" to disabilities in children who after all were undergoing rapid development (13). Contrarily, a study of HBRDs from a university hospital in 2015 reported that rate of permanent disability among children as $77.0 \%$ (9). In another study of adults receiving HBRDs $(n=795)$, rates for severe and permanent disability were reported as $39.4 \%$ and $64.2 \%$, respectively (16). Another study on a different adult sample reported severe and permanent disability among $56.7 \%$ and $57.6 \%$, respectively (9). In our study $83.5 \%$ of the sample were severely disabled while $66.5 \%$ of the patients were classified as having permanent disability. Those rates were higher than those previously reported and may reflect sampling bias as well as accepted clinical practice within the institution.

According to the 2010 TURKSTAT data, the most common reason for applying for HBRDs is mental disorders (17). When the frequency of diagnosis was determined from other areas except psychiatry, it was found that the diagnosis was most related to neurological problems (cerebral palsy $18.6 \%$, epilepsy $12.4 \%$, (8). Another study reported that $13.7 \%$ of their sample had seizures and $36.1 \%$ of cases had motor dysfunction (7). When the distribution of disturbances that cause disability among children applying for HBRDs is examined, another group reported that the most frequent disorders were mental/psychological/behavioral, followed by musculoskeletal and nervous system disorders, respectively (13). Another study also confirmed those results and reported that applicants for HBRDs mostly had musculoskeletal disorders and mental illnesses (18). Patients with musculoskeletal disorders may also be more likely to have severe and permanent disability (19). In our study, children with psychiatric, ear/nose/throat, pediatric, neurological and orthopedic disorders were more severely disabled than those without. Also, severe disability is most likely with pediatric disorders and mental disorders (especially MR/IDDs). Our results support and extend those from previous studies in that musculoskeletal disorders in children may be severely disabling along with other disorders. Among mental disorders, MR/IDDs may be especially disabling.

It is known that a majority of the MR/IDDs in the community are mild (i.e. $85.0 \%$ ) although rates in clinical populations may differ (18). Reflecting those results, mild MR/IDDs formed $32.2 \%$ of our population while the rests were moderate (i.e. $22.4 \%$ ) or severe (10.8\%). This difference may reflect later recognition and better functioning of milder MR/IDDs as well as elevated medical/psychiatric comorbidities is more severe MR/IDDs. According to the Turkish regulations, people whose disability rate is $50.0 \%$ or more and who depend on help to perform their daily living activities are considered to have "severe disability" (6). Also, according to Turkish barema mild MR/IDDs have a disability rating of $50.0 \%$ while moderate $(70.0 \%)$, severe $(90.0 \%)$ and profound $(100 \%)$ MR/IDDs are assigned greater disability ratings. In our study, severe disability was related with mild/moderate and severe MR/IDDs. This may reflect the fact that daily independent functioning rather than Intellectual Quotients in structured tests is more important in assessing disability. Also, toddlers and infants who naturally depend on others for their daily functioning are not adequately covered in the present regulation and may be assigned severe disability. A common approach in HBRDs in Turkish institutions is to provide permanent reports in life-long disorders (such as MR/IDDs and ASDs) depending on severity and the age of the applicant. Provision of permanent reports in such cases protects the family and the disabled child against repeated applications (11). In our study, pediatric, ophthalmologic, and cardiac disorders were found to have a high rate of permanent reports, but those with psychiatric disorders were found to have significantly lower rates. This may be related to the fact that the diagnostic stability of psychiatric diseases is lower than that of organic diseases. There is a need for further studies in this area. Additionally we found that permanent disability reports in the institution we studied were given in severe MR/IDD cases, while mild MR/IDD patients received temporary records. This may be due to the child's developmental stage, change in diagnostic status with rehabilitation as well as the desire of the physician to keep the hope of the parents alive and the need for follow-up depending on the variability of diagnostic stability.

In our study, ROC analysis for severely handicapped and persistent handicap indicated that the cut-off point was identified as 8 years for severe disability and 3 years for permanent disability. Those aged 8 years and younger were severely disabled, and those older than 3 is in the permanent reports group. This may reflect greater dependence on assistance of others for daily functioning in younger children as well as greater severity of disorders. Also, diagnostic stability may increase with greater age allowing reports for permanent disability. Supporting this position we found that as the age increases, the likelihood of receiving permanent disability reports increases by 4.324 times. Diagnostic variability of psychopathology is also reflected by the fact that permanent disability is more likely with non-psychiatric and less likely with psychiatric disorders.

Our results should be evaluated within their limitations. Firstly, the results are limited to a single-center and the patients reporting for HBRDs and may lack generalizability to other centers and other populations. Secondly, this is a chart review study and further, objective information on functioning (i.e. quality of life, psychometric scales and instruments) may have enriched our results. Regardless of those limitations our results suggest further avenues of research on factors associated with severe and permanent disabilities in children. Further, more detailed studies on this subject are required. 


\section{REFERENCES}

1. Peterson D. Conceptualizing, functioning, disabilitiy, and health. In: Falvo D, Holland BE, editors. Medical and psychosocial aspects of chronic illness and disability. 6th ed. Burlington MA: Jones \& Bartlett Learning, 2018. p.1-9.

2. World Health Organization, World Bank. World report on disability. Malta: World Health Organization; 2011.

3. State Institute of Statistics Prime Ministry Republic of Turkey, Presidency of Administration on Disabled People Prime Ministry Republic of Turkey. Turkey disability survey 2002. Ankara: State Institute of Statistics Prime Ministry Republic of Turkey; 2004.

4. Meral BF, Turnbull HR. Comparison of Turkish Disability Policy, the United Nations Convention on the Rights of Persons with Disabilities, and the core concepts of U.S. disability policy. Alter. 2016;10(3):221-35.

5. Council of Europe. Assessing Disability in Europe similarities and differences. Strasbourg: Council of Europe; 2002.

6. Republic of Turkey Ministry of Family, Labour and Social Services. [Özürlülük ölçütü, sınıflandırılması ve özürlülere verilecek sağlık kurulu raporları hakkında yönetmelik]. Resmi Gazete. 2012;28173.

7. Basgul SS, Saltik S. Göztepe Training and Research Hospital-disabled children committee -2010 data. Göztepe Tip Derg. 2012;27(2):45-9.

8. Şahin N, Altun H, Kara B. Assessment of disabled child health council reports. Kocatepe Med J. 2014;15(1):48-53.

9. Baltacı H, Kayhan Tetik B, Selçuk EB, Baltacı M. Analysis of cases referred to the disability board of Inonu University Turgut Ozal Medical Center in 2015. Türk Aile Hek Derg. 2017;21(3):91-100.

10. Yektaş Ç, Kaplan SE. Evaluation of health committee reports of patients admitted to the university of child and adolescent department. Konuralp Med J. 2017;9(3):52-6.

11. Özbaran B, Köse S. Health committee reports for disabled children in child psychiatry practice: the last six-year experience of Ege University. Turk J Child Adolesc Ment Health. 2011;18(1):67-72.

12. Akar T, Değirmenci B, Demirel B. Unbeachtet child neglect area: special education in disabled children. Turkiye Klinikleri J Foren Med. 2011;8(2):66-71.

13. Kaya A, Güler H, Meral O, Aktaş EÖ. The retrospective examination of the reports for the children with disabilities prepared by the disability board of Ege University Medical School. Güncel Pediatri. 2014;12(3):151-9.

14. Kuygun Karcı C, Güzel E, Sanberk S, Yolga Tahiroğlu A, Metin Ö. Abuse and neglect in children and adolescent who applied to mental disability report. Yeni Symposium. 2017;55(1):7-11.

15. World Health Organization. The global burden of disease: 2004 update. Geneva, Switzerland: World Health Organization, 2008.

16. Yıldız M, Özsoy F, Batmaz S, Songur E, Karakülah K. Investigation of medical board reports of disability due to mental health problems. Cukurova Med J. 2016;41(2):253-8.

17. Republic of Turkey Ministry of Family and Social Policies, Turkish Statistical Institute. Survey on problems and expectations of disabled people 2010. Ankara: Turkish Statistical Institute; 2011.

18. Uysal C, Bulut M, Kaya MC, Güneş M, Bez Y, Zeren $\mathrm{C}$, et al. Analysis of patients admitted to the disabled board of Dicle University Medical Faculty Hospitals. J For Med. 2013;27(1):1-9.

19. Terzi R, Altın F. Examination of the patient's locomotor system disability evaluated in the board of health for disabled. Turk J Osteoporos. 2014;20(2):60-4. 